\title{
Distribution of Nitrate Household Waste and Groundwater Flow Direction around Code River, Yogyakarta, Indonesia
}

\author{
Muryanto $^{1^{*}}$, Suntoro ${ }^{1}$, Totok Gunawan ${ }^{2}$, Prabang Setyono ${ }^{1}$, Afid Nurkholis ${ }^{3}$ and Nurisa F. Wijayanti ${ }^{3}$ \\ ${ }^{1}$ Department of Environmental Science, Universitas Sebelas Maret, Indonesia \\ ${ }^{2}$ Faculty of Geography, Universitas Gadjah Mada, Indonesia \\ ${ }^{3}$ Watershed Modeling Research Group, Faculty of Geography, Universitas Gadjah Mada, Indonesia
}

Received: 2019-02-12 Accepted: 2019-03-11

Keywords:

code river;

flownets;

groundwater quality;

nitrate contamination.

Corespondent Email:

65.muryanto@gmail.com

\begin{abstract}
The nitrate concentrations in shallow groundwater of the Yogyakarta City and its surroundings has increased to about twenty times in the period 1985-2018. The objective of this study was to analyse the distribution of nitrate concentrations in water well around the Code River, Yogyakarta. Flownets mapping was performed to find out the distribution and direction of potential groundwater pollution. Nitrate concentration was analysed by taking 18 groundwater samples scattered in the upstream, midstream and downstream areas of the Code River. The results of this study indicate that nitrate concentrations in the water well of upstream and downstream areas could still be used as a source of drinking water and recreation-irrigation-livestock. Meanwhile, the nitrate concentration in water well of the midstream area of the Code River, Yogyakarta City, mostly ( $80 \%$ of the sample) did not meet all classes of water quality standards. Human activities in the densely populated settlements were the main factors that influence nitrate pollution. Furthermore, groundwater flow in the study area leads from north to south and towards the Code River. This condition indicates that the nitrate concentrations in the groundwater can be a source of a pollutant for the Code River.
\end{abstract}

\footnotetext{
(c) 2019 by the authors. Licensee Indonesian Journal of Geography, Indonesia.

This article is an open access article distributed under the terms and conditions of the Creative Commons

Attribution(CC BY NC) licensehttps://creativecommons.org/licenses/by-nc/4.0
}

\section{Introduction}

Nitrate is a stable form of nitrogen which is similar to a conservative compound (Freeze \& Cherry, 1979). Due to the stable compound, nitrate concentration does not quickly change in physics, chemistry, and biology. Therefore, nitrate pollution becomes one of concern in the groundwater problem in the world. Commonly, excess nitrates in the human body can cause baby blue syndrome (WHO, 2003). Another negative impact of nitrate surpluses on health can refer to Chang et al. (2010); Kuo et al. (2007); Ward et al. (1996); Kostraba et al. (1992); and Sadeq et al. (2008).

According to Smith et al. (1999), human and animal's waste are the primary source of nitrate pollution in Asian Villages. In Java, Indonesia, nitrate concentrations in most wells used for drinking water exceed the standards by WHO, >50 mg/L (Wetselaar et al., 1993). The intensive establishment can increase nitrate concentrations in groundwater, as well as happened in Yogyakarta, Indonesia.

Yogyakarta's population growth in 2000 to 2000 was $1.04 \%$ per year and projected increase to $1.07 \%$ per year $(37,084$ people per year) in 2010 - 2020 (BPS, 2015; Bappeda D.I. Yogyakarta, 2016). This condition exacerbates groundwater nitrate pollution by the failure of on-site sanitation system (Putra, 2007; 2010; 2011). The previous research by Sudarmadji (1991) shows that nitrate concentration in Yogyakarta Municipality in 1985 were classified good, around 2.8
mg/L. According to Putra (2007), nitrate concentration in Yogyakarta increased to almost ten times, into 31.5 mg/L. Fathmawati et al. (2018) reported in 2017 that nitrate concentration in shallow unconfined aquifer in Yogyakarta City increase 20 times $(56.5 \mathrm{mg} / \mathrm{L})$ from 1985.

This study aimed to analyse the distribution of nitrate concentration in groundwater in the settlement area around Code River, Yogyakarta. The area around Code River is strategic because located in the downtown of Yogyakarta (Widodo et al., 2010;2013). However, water pollution is a serious problem that threatens this area. According to Widodo et al. (2013); Brahmantya \& Purnama (2010); and Imroatushoolikhah et al. (2014), Code River has been polluted, indicated by the quality that exceeds the drinking water quality standard by The Regulation of DIY Governor No 20, 2008. For these reasons, analysis of the source of the pollutant, especially nitrate, that causes pollution in The Code River is interesting research to do.

\section{Methods \\ Study Area}

The study occupied in around Code River which is part of the Code Watershed (4,188.2 Ha), as depicted in Figure 1. It is located in three administrative regions, Sleman Regency, Yogyakarta City, and Bantul Regency. 
The Code River flows from North to South with its upstream located on the southern slope of Merapi Volcano in the Sleman Regency, while its downstream recharge into Opak River in Bantul Regency (Figure 1).

Physiographically, the study area situated in Yogyakarta plain area as part of Solo Zones (Bemmelen, 1979). Hydrogeologically, the area around Code River is part of Yogyakarta - Sleman Groundwater basin (Decree of President of Republic Indonesia No.26, 2011). According to Hendrayana \& Vicente (2013), aquifer hydrostratigraphy in this area could be divided into three types, namely the unconfined aquifer, semi unconfined aquifer, and non-aquifer. The non-aquifer type consists of old Merapi deposits in the form of breccia and lahar deposit (Warsono, 1990).

The studied area was classified as a moonsonal climatic area with rainy season occurs during November - April, while the dry season occurs during May - October. Data from Indonesian Agency of Meteorology, Climatology, and Geophysical (BMKG) in the Tanjungtirto station shows that the average of rainfall during 30 years period $(1983$ - 2013) was 1,757 $\mathrm{mm}$ /year. Meanwhile, the mean temperature was 28.7 ${ }^{\circ} \mathrm{C}$. Besides, the study by Listyani et al. (2012) examined that water balance analysis in the Code Watershed shows good water availability in this area.

The study area divided into three locations, upstream (Sleman Regency), midstream (Yogyakarta City) and downstream (Bantul Regency). Furthermore, these three locations are divided into West part and East part of the Code River, as present in Figure 1. Selection of upstream-midstream-downstream locations considers the domination of settlement area around the Code River (Table 1). This condition accordance with the aim of this study, that is analysing the distribution of nitrate concentration in settlement area spatially

\section{Flownets Mapping}

Flownets (groundwater flow pattern) analysis is used to determine the distribution and direction of potential groundwater pollution. Groundwater flows not only transport water but also the chemical element which are contained in groundwater (Richardson et al., 1992). Flownet that combined with groundwater quality using GIS (Geographic Information System) approach useful for monitoring and managing groundwater quality (Sarvajayakesavalu et al., 2018 and Rawat et al., 2018).

In this study, flownets made with three-point problem method. This method interpolates three nearest water level measurement point (Fetter, 1988). The direction of groundwater flows determinate by drawing a perpendicular line of water level contour from the highest to the lowest hydraulic head. The sampling of groundwater level performed on 43 (24 samples in the west part of the river and 19 samples in the east) wells with the characteristic of a shallow unconfined aquifer. It was carried out in March which is the end of rainy season. Then, the entire sample was interpolated using ArcMap 10.3 software.

\section{Nitrate Analysis}

The sample for nitrate analysis was performed on wells and springs water. There are 16 samples for water wells in upstream, midstream, and downstream also two samples in springs which located in the southern slope of Merapi volcano (Figure 1). The sample of groundwater taken on 16 water wells in upstream, midstream and downstream. Two samples were taken on water springs located in the south slope of Merapi volcano (Figure 1). The water samples were taken as much as $100 \mathrm{ml}$ for each location. Nitrate concentration analysed in the Laboratory of Hydrology and Climatology, Faculty of Geography, Universitas Gadjah Mada following the National Standardization (SNI 6989.79: 2011). Furthermore, nitrate concentration being analysed based on water quality standard, determined by Regulation of DIY Governor No 20, 2008 (Table 2).

\section{Result and Discussion Groundwater Flow Pattern}

Groundwater flow pattern map for six study area is presented in Figure 2. Generally, groundwater flows from North to South due to the lower hydraulic gradient in the North area towards the southern coast of Yogyakarta. Hendrayana \& Vicente (2013) point out that the groundwater of Yogyakarta - Sleman aquifer

Table 1. Landuse in the study area*

\begin{tabular}{lllllll}
\hline Land use & $\begin{array}{l}\text { Upstream } \\
\text { Area (Ha) }\end{array}$ & $\%$ & Area (Ha) & $\%$ & Area (Ha) & $\%$ \\
\hline Settlement & 1,499 & $32 \%$ & 1,166 & $89 \%$ & 572 & $32 \%$ \\
Rice Field & 2,015 & $43 \%$ & 94 & $7 \%$ & 1,037 & $57 \%$ \\
Plantation & 842 & $18 \%$ & 8 & $1 \%$ & 186 & $10 \%$ \\
Shrubs & 131 & $3 \%$ & 38 & $3 \%$ & 12 & $1 \%$ \\
Forest & 172 & $4 \%$ & 0 & $0 \%$ & 0 & $0 \%$ \\
Total & 4,659 & $100 \%$ & 1,306 & $100 \%$ & 1,807 & $100 \%$ \\
${ }^{*}$ source: Map of Rupa Bumi Indonesia (RBI) scale 1:25,000 in the years of 2017 by \\
National Mapping Agency of Indonesia (BIG)
\end{tabular}




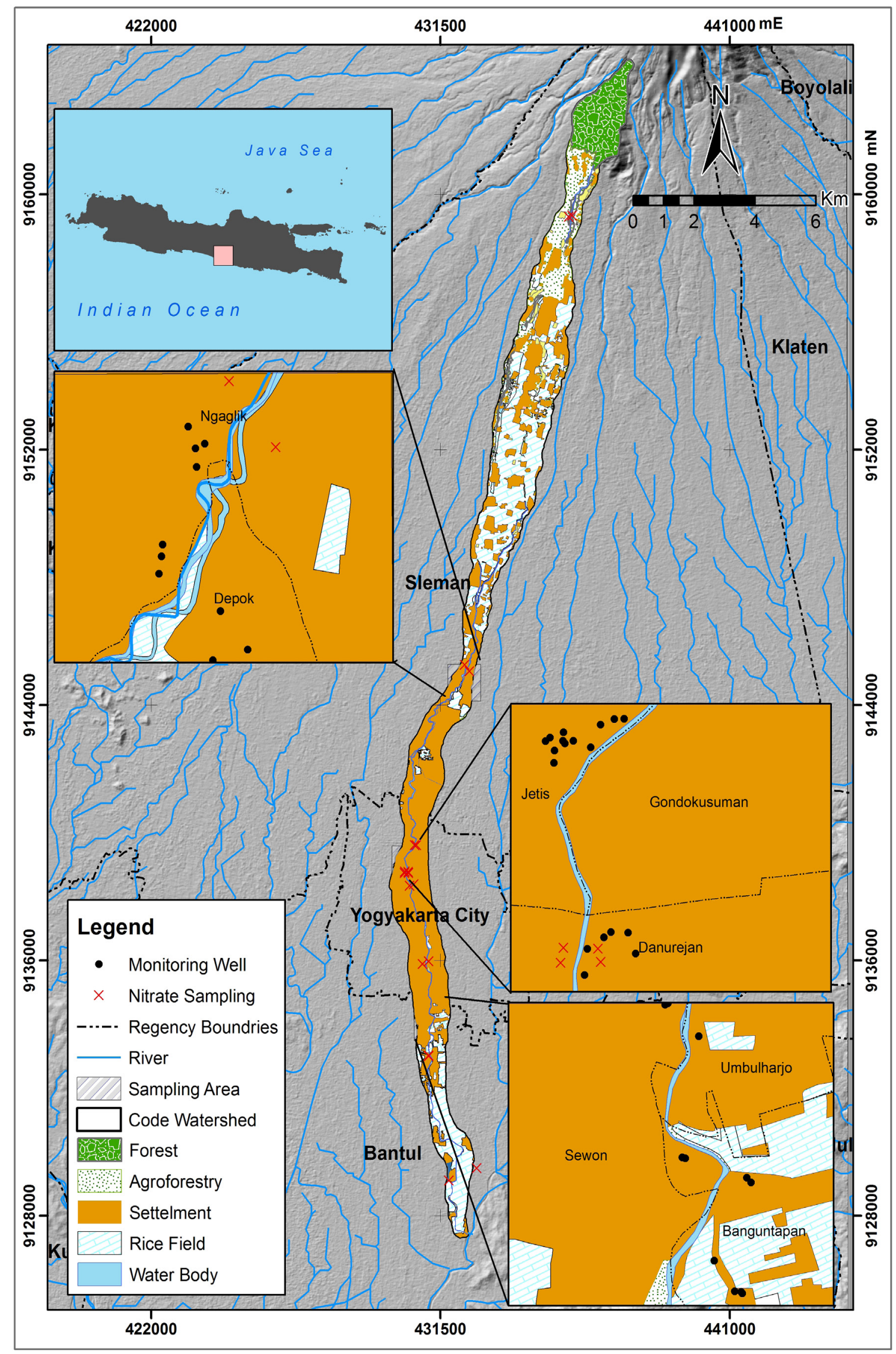

Figure 1. The study area 


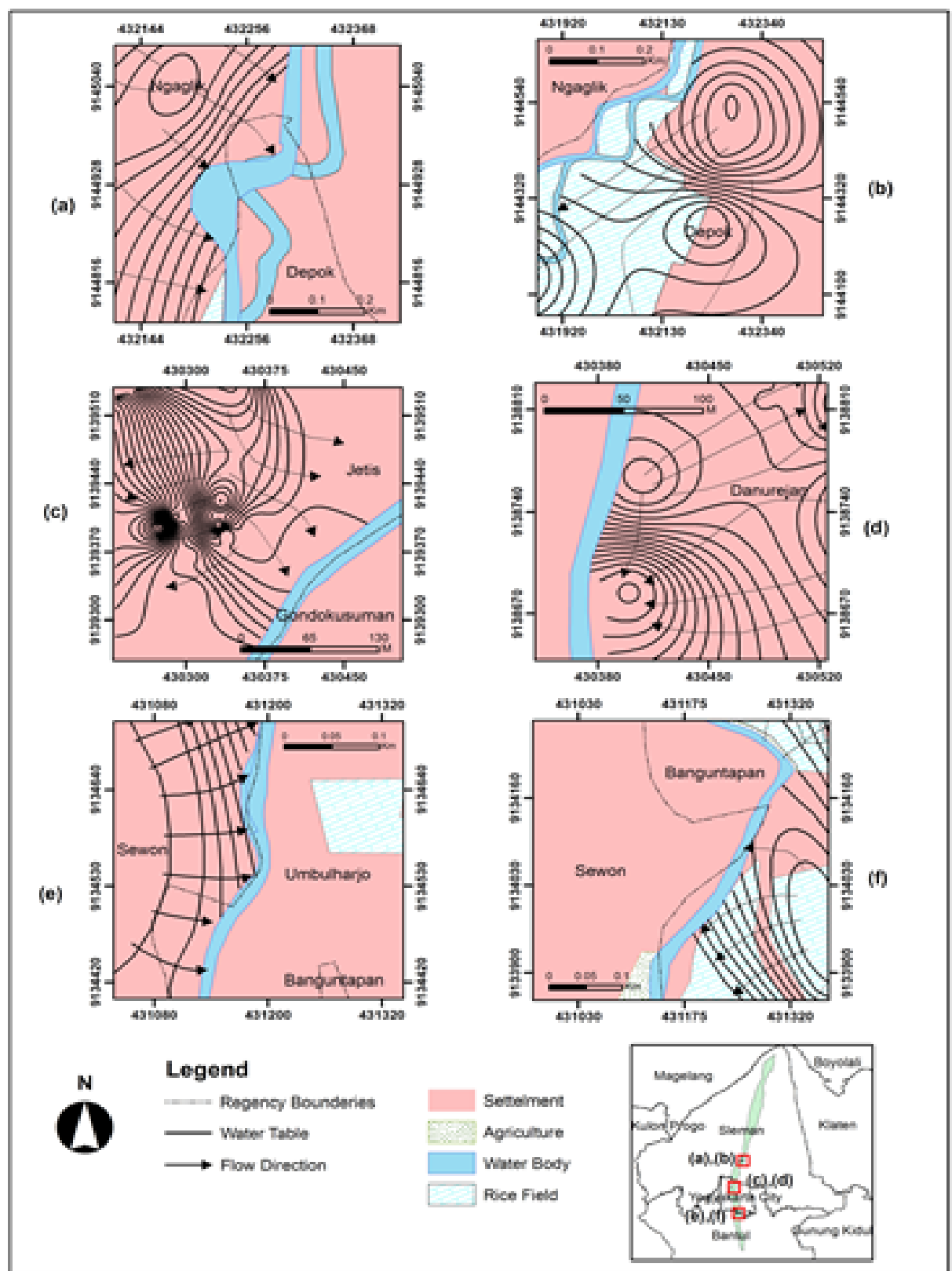

Figure 2. Groundwater flow pattern in (a) left-upstream, (b) right-upstream, (c) left-midstream, (d) right-midstream, (e) left-downstream, (f) right-downstream

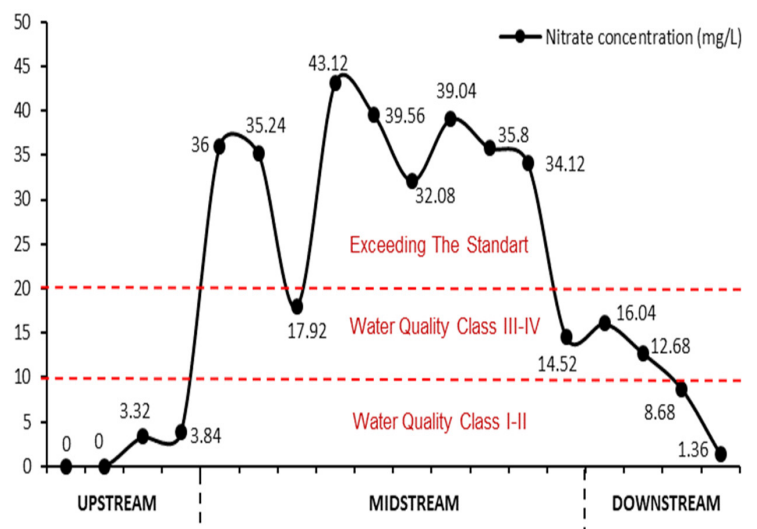

Figure 3. Distribution of nitrate concentration
Table 2. Water quality classification based on Regulation of Yogyakarta Special Region Governor No. 20, 2008.

\begin{tabular}{lll}
\hline $\begin{array}{l}\text { Nitrate Concen- } \\
\text { tration }(\mathrm{mg} / \mathrm{L})\end{array}$ & $\begin{array}{l}\text { Water Quali- } \\
\text { ty Classifica- } \\
\text { tion }\end{array}$ & $\begin{array}{l}\text { Utilisation of } \\
\text { water }\end{array}$ \\
\hline$<10$ & I - II & $\begin{array}{l}\text { Drinking water } \\
\text { and recre- } \\
\text { ation-irriga- } \\
\text { tion-livestock } \\
\text { Recreation-irri- } \\
\text { gation-livestock }\end{array}$ \\
& III - IV & \\
\hline
\end{tabular}


Table 3. The comparison of nitrate concentration with previous studies

\begin{tabular}{|c|c|c|c|}
\hline \multirow{2}{*}{$\begin{array}{l}\text { Nitrate Concentration } \\
(\mathrm{mg} / \mathrm{L})\end{array}$} & \multicolumn{3}{|c|}{$\mathrm{n}$} \\
\hline & This study (2018) & Fathmawati et al. (2018) & Putra (2010) \\
\hline \multicolumn{4}{|l|}{ Upstream } \\
\hline$<10$ & 4 & 5 & 3 \\
\hline $10-50$ & 0 & 3 & 3 \\
\hline $50-100$ & 0 & 0 & 2 \\
\hline$>100$ & 0 & 0 & 0 \\
\hline \multicolumn{4}{|l|}{ Midstream } \\
\hline$<10$ & 0 & 0 & 0 \\
\hline $10-50$ & 10 & 3 & 3 \\
\hline $50-100$ & 0 & 5 & 2 \\
\hline$>100$ & 0 & 2 & 5 \\
\hline \multicolumn{4}{|l|}{ Downstream } \\
\hline$<10$ & 2 & 1 & 2 \\
\hline $10-50$ & 2 & 3 & 2 \\
\hline $50-100$ & 0 & 0 & 0 \\
\hline$>100$ & 0 & 0 & 0 \\
\hline Total Samples & 18 & 22 & 22 \\
\hline
\end{tabular}

dominantly flows to the South with some local changes towards the rivers. In this study, the flownets map also shows that the water from aquifer flows toward Code River (effluent stream condition) due to the lower of its water level compared to the aquifer. This condition causes the Code River to flow continuously during years (perennial river), as explained by Listyani et al. (2012).

The exceptions of these conditions occurred in the east part of the Code River's midstream area. The influent stream condition occurred as indicated by the water that flows toward the aquifer. Figure $2 b-c$ examined that the condition occurred in the dominant settlement area in the Jetis, Gondokusaman, and Danurejan districts. According to Manny et al. (2016), the districts encountered a groundwater level decline to about 1-6 meters in the 1985-2015 period due to the overexploitation of groundwater in the settlement area. Previous researches by Putranto \& Kusuma (2009); Taufiq et al. (2018); and Lubis (2018) showed that large cities in Java, Indonesia are threatened with subsidence, seawater intrusion and pollution due to excessive used of groundwater.

Furthermore, groundwater flows in upstream, midstream, and downstream that toward the river indicated the Code River is vulnerable to pollution. The result of the study supports the previous research by Widodo et al. (2013) and Imroatushoolikhah et al. (2014), which stated that Code River had been contaminated with nitrate that has exceeded drinking water standard at the outlet of the river $(24.5 \mathrm{mg} / \mathrm{L})$

The nitrate concentration from 18 samples is shown in Figure 3. It showed that Code River's upstream has the best groundwater quality, where all four samples have nitrate concentrations $<10 \mathrm{mg} / \mathrm{L}$. There are even two samples that had $0 \mathrm{mg} / \mathrm{L}$ of nitrate concentration which located in south slope of Merapi volcano (the springs). This condition indicates that the area around Code River in Sleman Regency has class III groundwater quality, which can be used for drinking water and recreation-irrigation-livestock. Good quality of groundwater in the upstream area can be caused by the relatively non-dense settlement area (32\%), as shown in Table 1. As pointed out by Smith et al. (1999) and Wetselaar et al. (1993), groundwater pollution in Java mainly affected by disposal of domestic human waste.

The midstream area has the worst nitrate concentration. Figure 3 showed that $80 \%$ of the sample in this study are not meet the water quality standard. Meanwhile, only two samples meet the criteria for groundwater quality to be used as recreation-irrigation-livestock (class III-IV). This condition reflects that groundwater in Yogyakarta City not suitable used as drinking water. Nitrate concentration that exceeded water quality standard caused by the domination of the settlement area, which shows $89 \%$ in Yogyakarta City (Table 1).

The Code River's downstream area has two samples of nitrate concentration that meet the standard of water quality class I-II and also two samples classified as class III-IV. Rather than the midstream area this condition is better but compared to the upstream area it is worse. However, two samples with class III-IV were in the 


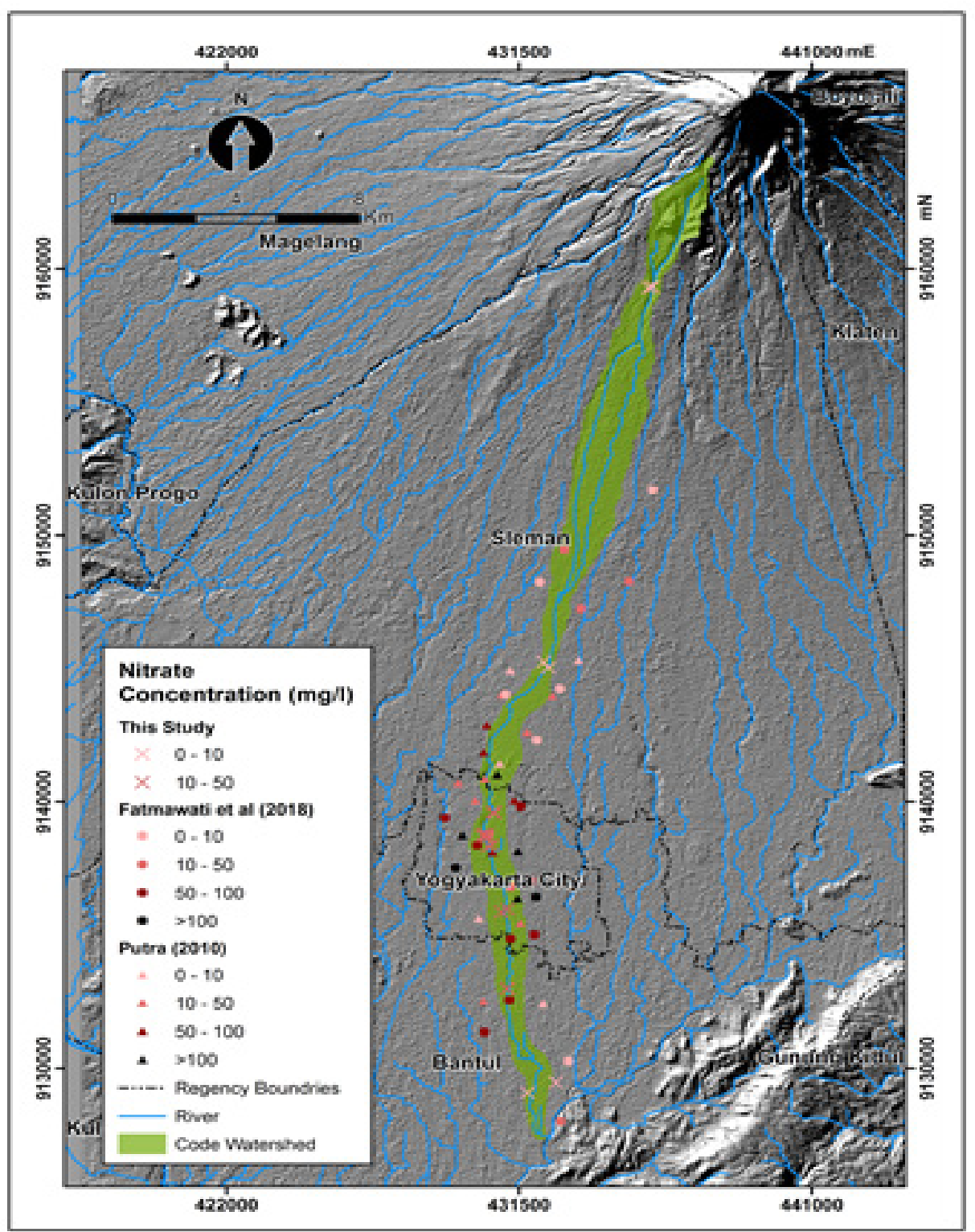

Figure 4. Nitrate concentration around Code River from this study, Putra (2010), and Fathmawati et al. (2018)

area that directly adjacents to the midstream area (Yogyakarta City). Prastoro (2009) and Fathmawati et al. (2018) affirmed that the Bantul Regency mainly tend to have low nitrate concentrations, except in areas that adjacent to the Yogyakarta. This condition was caused by the development of the Yogyakarta urban agglomeration which includes the surrounding areas. The Yogyakarta urban agglomeration (Pemerintah DIY, 2005) is a crowded city which caused the decreasing quality of groundwater due to improper sanitation system (Heng et al., 2010; Putra, 2010; Fathmawati et al., 2018). Figure 4 examined that three samples by Putra (2010) which located in the Sleman Regency and adjacent to the Yogyakarta City has high nitrate concentrations $(50-100 \mathrm{mg} / \mathrm{L}$ and $>100 \mathrm{mg} / \mathrm{L})$

The research result above was also confirmed by Putra (2010) and Fathmawati et al. (2018). Both of them analysed nitrate concentration at the water well in Yogyakarta City and its agglomeration. Several samples in the vicinity of the Code River's area were analyzed in this study, as depicted in Figure 4 and Table 3.

Table 3 shows that the upstream and downstream of Code River's area still have tolerable groundwater quality based on its nitrate concentration. The samples in both locations showed the dominance on $<10$ $\mathrm{mg} / \mathrm{L}$ and partly on $<50 \mathrm{mg} / \mathrm{L}$. Two samples by Putra (2010) that have nitrate concentration 50-100 mg/L located in Yogyakarta City's agglomeration (Figure 4). Meanwhile, the midstream of Code River's area has the worst groundwater quality. All samples have nitrate concentration that does not meet the water quality standard for drinking water $(>10 \mathrm{mg} / \mathrm{L})$. Moreover, seven samples have extremenitrate concentration $(>100 \mathrm{mg} / \mathrm{L})$.

The dominance of the settlement area caused the 
worst groundwater quality in the midstream of Code River's area. Putra (2010) and Fathmawati et al. (2018) pointed out that the highest nitrate concentration in the water wells of Yogyakarta City originally came from human faces due to lack of on-site sanitation. However, this study did not compare the ratio between nitrate and chloride concentration to determine the effect of human faces on water quality as explained by ARGOSS (2011) and Morris et al. (2003). Nevertheless, the selection of the study area which is in the settlement dominance area corroborates the result of this study, that is the high nitrate concentration in the midstream area of Code River affected by the dominance of settlement areas.

The above state is also emphasised by Smith et al. (1999) who conducted research in Kotagede, Yogyakarta City. High nitrate concentration in water wells mostly caused by septic tank, since the unsaturated zone above the tanks has low nitrate concentration while below's have higher. Furthermore, the nitrate concentrations are determined by some main factors, namely: the strength of the source, the rainfall amount and distribution, the soil characteristics, the direction and flow velocity of the aquifer, and the distances between nitrate sources and wells.

\section{Conclusion}

The result of this study shows that nitrate concentration in water wells of the Code River's upstream are can be used for drinking water and recreationirrigation-livestock purposes. Meanwhile, most of the water well in the midstream of Code River's area exceed the water quality standard. This condition becomes urgent considering the population in the Yogyakarta City only depend on the groundwater resources to fulfil their needs for fresh water. In the downstream adjacent to the midstream area, nitrate concentration has a worse water quality standard compared to locations that far away from the midstream area.

Furthermore, the flownets mapping shows that the groundwater flows toward the South direction and the Code River. This condition causes the Code River becomes very vulnerable to water pollution. Also, follow-up studies can be conducted by using distributed or semi-distributed hydrological modelling, such as SWAT, QUAL2KW, and WASP. The hydrological modelling software can analyse the relationship between point source and non-point source of nitrate concentration toward the water quality of Code River. Thereby, evaluation and prediction regarding water quality in the area around Code River become more comprehensive.

\section{References}

ARGOSS. (2001). Guidelines for assessing the risk to groundwater from on-site sanitation. British Geological Survey Commissioned Report, CR/01/142, 97pp.

Badan Pusat Statistik. (2015). Proyeksi Penduduk Kabupaten/ Kota Provinsi DI Yogyakarta 2010 - 2020. Jakarta: Badan
Pusat Statistik, Indonesia. (in Indonesian)

Badan Standardisasi Nasional. (2011). Air dan air limbah - Bagian 79: Cara uji nitrat (NO3-N) dengan spektrofotometer UV-visibel secara reduksi kadmium. SNI 6989.79, (3). https://doi.org/SNI 6989.79:2011 (in Indonesian)

Bappeda D.I. Yogyakarta. (2016). Analisis Informasi Statistik Pembangunan Daerah Istimewa Yogyakarta 2016. Yogyakarta: Badan Perencanaan Pembangunan Daerah D.I. Yogyakarta. (in Indonesian)

Brahmantya, Y., Purnama, I.S. (2010). Kualitas Airtanah Sub DAS Code Kota Yogyakarta Pasca Erupsi Merapi Tahun 2010. Jurnal Bumi Indonesia. 22(2), 178-189. (in Indonesian)

Chang, C.-C., Chen, C.-C., Wu, D.-C., \& Yang, C.-Y. (2010). Nitrates in drinking water and the risk of death from rectal cancer: does hardness in drinking water matter?. Journal of Toxicology and Environmental Health. Part A, 73(19), 1337-1347. https://doi.org/10.1080/15287394.20 10.490178

Fathmawati, F., Fachiroh, J., Sutomo, A.H., \& Putra, D.P.E. (2018). Origin and distribution of nitrate in water well of settlement areas in Yogyakarta, Indonesia. Environmental Monitoring and Assessment. 190(11). https://doi.org/10.1007/s10661-018-6958-y

Fetter, C.W. (1988). Applied Hydrology. Ohio: Merrill Pubs. Co. Columbus Ohio United States of America.

Freeze, R. A., \& Cherry, J. A. (1979). Groundwater. New Jersey: Prentice-Hall, Inc.

Pemerintah Republik Indonesia. (2011). Keputusan Presiden Republik Indonesia Nomor 26, Tahun 2011. (in Indonesian)

Hendrayana, H., \& Vicente, V. A. D. S. (2013). Cadangan Air Tanah Berdasarkan Geometri Dan Konfigurasi Sistem Akuifer Cekungan Air Tanah Yogyakarta-Sleman. Prosiding Seminar Nasional Kebumian Ke-6 Teknik Geologi Universitas Gadjah Mada. 356-370 pp. (in Indonesian)

Heng, S., Putra, D. P. E., \& Wilopo, W. (2010). The impact of sanitation on groundwater nitrate level in Bantul District, Bantul Regency, Yogyakarta Special Province, Indonesia. Journal of South East Asian Applied Geology. 2(2), 129-137 Imroatushoolikhah., Purnama, I.S., \& Suprayogi, S. (2014). Kajian Kualitas Air Sungai Code Provinsi Daerah Istimewa Yogyakarta. Majalah Geografi Indonesia. 28(1), 23-32. (in Indonesian)

Kostraba, J. N., Gay, E. C., Rewers, M., \& Hamman, R. F. (1992). Nitrate levels in community drinking waters and risk of IDDM: An ecological analysis. Diabetes Care, 15(11), 1505-1508. https://doi.org/10.2337/diacare.15.11.1505

Kuo, H. W., Wu, T. N., \& Yang, C. Y. (2007). Nitrates in drinking water and risk of death from rectal cancer in Taiwan. Journal of Toxicology and Environmental Health - Part A: Current Issues, 70(20), 1717-1722. https://doi. org/10.1080/15287390701457704

Listyani, T.R.A., Isjudarto, A., \& Putra, R. I. (2012). Analisis Hidrologi untuk Mendukung Potensi Airtanah Pada Sub DAS Code. Prosiding Seminar Nasional Aplikasi Sains \& 
Teknologi (SNAST) Periode III, Yogyakarta 3 November 2012, 220-227 pp. (in Indonesian)

Lubis, R.F. (2018). Urban hydrogeology in Indonesia: A highlight from Jakarta. IOP Conference Series: Earth and Environmental Science. 118(1). https://doi. org/10.1088/1755-1315/118/1/012022

Morris, B. L., Lawrence, A.R. L., Chilton, P.J.C., Adam, B., Calow, R.C., \& Klinck, B.A. (2003). Groundwater and its Susceptibility to Degradation: A global assessment of the problem and option for management. Nairobi, Kenya: Early Warning and Assessment Report Series, RS. 03-3. United Nations Environment Programme.

Pemerintah DI. Yogyakarta. (2005). Peraturan Daerah, Daerah Istimewa Yogyakarta. (in Indonesian)

Prastoro, R.A. (2009). Tingkat Risiko Pencemaran Airtanah Bebas oleh Senyawa Nitrat di Kabupaten Bantul, Daerah Istimewa Yogyakarta: Studi Kasus Kecamatan Bantul dan Bambanglipuro. Tesis, Fakultas Geografi, Universitas Gadjah Mada. (in Indonesian with English abstract)

Putra, D.P.E. (2007). The impact of urbanization on groundwater quality; a case study in Yogyakarta City-Indonesia. Mitteilungen zur Ingenieurgeologie und Hydrogeologie, heft 96, Rheinisch-Westfalische Technische Hochschule Aachen.

Putra, D.P.E. (2010). Estimation, reality and trend of groundwater nitrate concentration under unsewered area of Yogyakarta City-Indonesia. J. SE Asian Appl. Geol. 2(1), 20-27.

Putra, D.P.E. (2011). Evolution of groundwater chemistry on shallow aquifer of Yogyakarta City urban area. J. SE Asian Appl. Geol. 3(2), 116-124.

Putranto, T.T., \& Kusuma, K.I. (2009). Permasalahan airtanah pada daerah urban. Jurnal Teknik. 30(1), 48-58. (in Indonesian)

Rawat, K. S., Jacintha, T.G.A., \& Singh, S.K. (2018). Hydrochemical Survey and Quantifying Spatial Variations in Groundwater Quality in Coastal Region of Chennai , Tamilnadu , India - a case study. Indonesian Journal of Geography. 50(1), 57-69.

Richardson, J.L., Wilding, L.P., \& Daniels, R.B. (1992). Recharge and discharge of groundwater in aquic conditions illustrated with flownet analysis. Geoderma. 53(1-2), 65-78. https://doi.org/10.1016/00167061(92)90021-X

Sadeq, M., Moe, C. L., Attarassi, B., Cherkaoui, I., ElAouad, R., \& Idrissi, L. (2008). Drinking water nitrate and prevalence of Methemoglobinemia among infants and children aged 1-7 years in Moroccan areas. International Journal of Hygiene and Environmental Health, 211, 546554. https://doi.org/10.1016/j.ijheh.2007.09.009.

Sarvajayakesavalu, S., Lakshminarayanan, D., George, J., Magesh, S.B., Anilkumar, K.M., Brammanandhan, G.M., \& Ravikumar, M. (2018). Geographic Information System mapping of gross alpha/beta activity concentrations in groundwater samples from Karnataka, India: A preliminary study. Groundwater for Sustainable Development. 6, 164-168. https://doi.org/10.1016/j. gsd.2017.12.003
Smith, G.D., Wetselaar, R., Fox, J.J., Van De Graaff, R.H. M., Moeljohardjo, D., Sarwono, J., \& Basuki. (1999). The origin and distribution of nitrate in groundwater from village wells in Kotagede, Yogyakarta, Indonesia. Hydrogeology Journal, 7(6), 576-589. https://doi. org/10.1007/s100400050230

Sudarmadji. (1991). Agihan geografi sifat kimiawi airtanah bebas di Kotamadya Yogyakarta. Disertasi, Fakultas Geografi, Universitas Gadjah Mada. (in Indonesian with English abstract)

Taufiq, A., Hosono, T., Ide, K., Kagabu, M., Iskandar, I., Effendi, A.J.,\& Shimada, J. (2018). Impact of excessive groundwater pumping on rejuvenation processes in the Bandung basin (Indonesia) as determined by hydrogeochemistry and modeling. Hydrogeology Journal. 26, 1263-1279. https://doi.org/http://dx.doi. org/10.1007/s10040-017-1696-8

Van Bemmelen, R.W. (1970) The geology of Indonesia. General Geology of Indonesia and Adjacent Archipelagoes. The Haque, Government Printing Office.

Ward, M. H., Mark, S. D., Cantor, K. P., Weisenburger, D. D., Correa-Villaseñor, A., \& Zahm, S. H. (1996). Drinking water nitrate and the risk of non-Hodgkin's lymphoma. Epidemiology, 7(5), 465-471. https://doi. org/10.1097/00001648-199609000-00003

Warsono, S. (1990) Survei Konservasi Airtanah Daerah Istimewa Yogyakarta. Bandung: Direktorat Jendral Geologi dan Sumberdaya Mineral, Direktorat Geologi Tata Lingkungan. (in Indonesian)

Widodo, B., Lupiyanto, R., \& Wijaya, D. (2010). Pengelolaan Kawasan Sungai Code Berbasis Masyarakat. Jurnal Sains \& Teknologi Lingkungan. 2(1), 07-20. https://doi. org/10.20885/jstl.vol2.iss1.art2 (in Indonesian)

Widodo, B., Kasam., Ribut, L., \& Ike, A. (2013). Strategi Penurunan Pencemaran Limbah Domestik di Sungai Code DIY. Jurnal Sains \&Teknologi Lingkungan. 5(1), 36-47. https://doi.org/10.20885/jstl.vol5.iss1.art5 (in Indonesian)

Wetselaar, R., Fox, J.J., Smith, G.D., Rum , A.M., Moermanto, R.J \& Ahmad, I. (1993). Groundwater nitrate in East Java, Indonesia. Aust Geol Surv Org J, Aust Geol Geophys. 14 :273-27

WHO. (2003). Nitrate and nitrite in drinking water. Background Document for Development of WHO Guidelines for Drinking-water Quality, World Health Organization, Geneva. 